\title{
Retraction: In Vitro antioxidant and anticancer activity of young Zingiber officinale against human breast carcinoma cell lines
}

Shahedur Rahman ${ }^{1 *}$, Faizus Salehin ${ }^{2}$ and Asif |qbal ${ }^{1}$

The journal has retracted this article [1] because it contains large portions of text that were duplicated from articles previously published in The Journal of Medicinal Plants Research [2] and Molecules [3].

\begin{abstract}
Author details
'Department of Biotechnology and Genetic Engineering, Islamic University, Kushtia 7003, Bangladesh. ${ }^{2}$ Department of Biotechnology and Genetic Engineering, University of Development Alternative, Dhaka, Bangladesh.
\end{abstract}

Received: 1 November 2012 Accepted: 1 November 2012

Published: 2 November 2012

\section{References}

1. Rahman S, Salehin F, labal A: In vitro antioxidant and anticancer activity of young Zingiber offincinale against human breast carcinoma cell lines. BMC Complement Altern Med 2011, 11:76.

2. Ghasemzadeh A, Jaafar HZE: Antioxidant potential and anticancer activity of young ginger (Zingiber officinale Roscoe) grown under different $\mathrm{CO} 2$ concentration. J Medicinal Plants Research 2011, 5(14):3247-3255.

3. Ghasemzadeh A, Jaafar HZE, Rahmat A: Elevated carbon dioxide increases contents of flavonoids and phenolic compounds, and antioxidant activities in Malaysian Young Ginger (Zingiber officinale Roscoe.) Varieties. Molecules 2010, 15:7907-7922.

\footnotetext{
* Correspondence: shahed.rajib@gmail.com

'Department of Biotechnology and Genetic Engineering, Islamic University, Kushtia 7003, Bangladesh

Full list of author information is available at the end of the article
}

\section{Submit your next manuscript to BioMed Central and take full advantage of:}

- Convenient online submission

- Thorough peer review

- No space constraints or color figure charges

- Immediate publication on acceptance

- Inclusion in PubMed, CAS, Scopus and Google Scholar

- Research which is freely available for redistribution 